\title{
Evaluation of Syrian Students' Dictation Texts (A2 Level)
}

\author{
Hüseyin Özçakmak ${ }^{1, *}$ \\ ${ }^{1}$ Turkish Language Education, Faculty of Education, Hatay Mustafa Kemal University, Hatay, Turkey \\ *Correspondence: Faculty of Education, Hatay Mustafa Kemal University, Antakya, Hatay, Turkey. Tel: \\ 90-530-345-8007. E-mail: huseyinozcakmak@gmail.com
}

A part of this study was presented as an oral presentation at the "2nd International Congress on Multidisciplinary Studies" held on 4-5 May 2018, Adana-Turkey.

Received: December 4, 2018

Accepted: January 22, 2019 Online Published: February 19, 2019

doi:10.5430/wje.v9n1p179

URL: https://doi.org/10.5430/wje.v9n1p179

\begin{abstract}
The study aiming to evaluate dictation texts of A2 level Syrian students is carried out with 19 students learning Turkish in university, 7 female and 12 male, whose age range between 20-24. In this qualitative pattern study, dictation papers written by students were considered as data collection tool. The book of Forsa from Omer Seyfettin was utilized in the study. Texts dictated by the researcher were written down by the students and resulting research data was analyzed in various aspects. In the study lasting 4 weeks; on $1^{\text {st }}$ week a text of 117 words consisting of 3 paragraphs, on $2^{\text {nd }}$ week a text of 121 words consisting of 4 paragraphs, on $3^{\text {rd }}$ week a text of 92 words consisting of 2 paragraphs and on $4^{\text {th }}$ week a text of 152 words consisting of 3 paragraphs was worked on. To minimize the mistakes, resarch data was inspected twice. In the end of the study, it was found that students were completing dictation practices with an increasing pace, the amount of correct words written by the students was higher than expected, dictation practice accelerated students' writing swiftness and students developed their writing skills. Also in the research, it was observed that students fell short of writing Arabic-rooted words in dictation texts, on the contrary to the expectations.
\end{abstract}

Keywords: dictation, Syrian students, A2 level, Arabic-rooted words

\section{Introduction}

In today's world, it is necessary for every individual to learn a language other than their native language. Especially in European Life Long Learning Competencies, European Commission and OECD reports, the competency of each individual learning at least one foreign language was more emphasized (Donger, Ozkartal, Sarigoz, 2016 \& 2017). Therefore learning a foreign language was accepted as one of the seven key competencies of life long learning, it was supported for every individual to learn at least one foreing language at reading, writing, listening and speaking aspects, and learning foreign language was divided to levels (Sarigoz, 2016). A2 level person, which is one level higher than beginner level of A1, has the ability to listen, read, write, talk and communicate known daily expressions in a foreign language about daily life, experiences, health and nutrition, environment, nature and rules, science, art and technology (MEB, 2015, p. 3).

The skill of dictation includes abilities of listening, reading, and speaking in addition to writing. Dictation is expressed as reading and dictating the writing of a text (Gogus, 1978, p. 476). The term dictation is described in Turkish Dictionary as making someone write at the moment by dictating (TDK, 2011, p. 662). Dictation is a multi-stage task involving; writing down a text that was listened (Gocer, 2010), in other words embodiment of the abstract voices of speaking through writing (Hengirmen, 1990), interpreting audial sounds as meaningful words and writing meaningful words in texts (Rapp \& Caramazza, 1997). Dictation is conveyance of audial language symbols (speaking) to secondary graphs (texts) and restatement of verbal symbols in written form (Sutherkand, 1967).

During the dictation; texts being voiced by the teacher (speaking) are heard through ears by students (listening), written down in the notebook (writing), and in the meantime emphasis, intonation and repetitions are learned. The texts voiced by teachers significantly help students who may not understand whether the information told is important. Thus, students can comprehend which elements are more important from the teacher's tone of voice. 
Dictation is a skill that is mostly mistaken for note taking. Note taking includes choosing the important and functional one (Ozcakmak, 2015, p. 38) whereas dictation is writing down what is being read as is. In other words; selection of information is emphasized on note taking while writing down the speech with exact words is considered important in dictation. In this sense, dictation can be regarded as exact note taking practice (Yalcin, 2002, p. 129). Although note taking is based on writing the valuable information, there are some cases where exact (one to one) note taking technique might be compulsory. For instance, writing a phone number or and address are some of these cases of exact note taking. The main difference between exact note taking and dictation practice is that note taking occurs during conversation while dictation takes place during (oral) reading. However, both of the skills are used effectively during the education period.

Because of dictation exercises, the individual will learn to use his/her native language effectively, in another saying, forming sentences with every words that was constructed by combining sounds and sharing feelings and thoughts in the process (Gultekin \& Aktay, 2014).

Dictation work can be actively utilized in classrooms but the activity is largely related to the process and usage (Sutherland, 1967). There should be special care on some matters when picking the texts to practice dictation works. Firstly, the selected text is expected to be short, complete in terms of subject, appropriate by spelling rules, encouraging for research and learning (Gogus, 1978, p. 379).

Dictation Works are usually carried out in classrooms at normal pace. However, most educators state that dictation Works should be applied at slow to average pace for students in beginner levels (Sutherkand, 1967). The text must be read three times, the pace should be in general conversation pace with no stoppage in first and third tries, in second try there should be some break during the recitement of the text to allow participants to write down what they hear (Jafarpur \& Yamini, 1993). Gogus (1978, p. 379) argues that text should be read slowly, propositional phrases and word groups should be voiced in their natural flow with no stoppage in dictation practices.

Dictation may not only involve students' writings of the text read or voiced but can be applied in different techniques or in various activities. In this sense, 13 dictation activities were expressed by Bozkurt, Bulbul \& Demir (2014) within dictation techniques. These activities are;

- Answers to status questions

- Changing the tenses of times

- Gap-filling dictation

- Dictation between students and forming new texts

- Numbers

- Dictation-test game

- The composition of dictation

- Story animation

- Comments with dictation

- Running dictation

- Noisy dictation

- Half story and

- Teahcer as a tape recorder type dictation.

Dictation is a method mostly used in writing education (Gogus, 1978, p. 378). Dictation can be used by teachers to consider students' writing levels and to see if the rule has been learned (Gogus, 1978, p. 379; Oz, 2011). Dictation can also be utilized as a test tool to check students' progresses in language (Sutherland, 1967). Indeed, in a research organized by Bolukbas (2011) which is conducted on Arab students, in order fo the students to correct the mistakes they made in writing (55\%), dictation studies are suggested and first of all, it is emphasized that students should be checked out whether they learned the languge fully or not. This situation shows that dictation can be used as an evaluation instrument to measure written expression skills. In fact, Coskun, Taskaya and Bal (2013) approach to dictation as one of the methods which can be used in assessment and evaluation supports this idea.

Dictation studies are not peculiar to language teachers. Teachers who are teaching in various fields such as English, Science, Mathematics, and Social Studies can also benefit fom dictation studies. Dictation can be easily used in teaching notions of disciplines and making them absorb mathematical problems. Dictation studies can also made use 
of reinforcing concepts which students do not know or begin to learn (Gladwin-Chocolaad, 1986). Teachers can reserve the last 15 minutes of each class to dictate texts formed of short paragraphs on purpose to make them understand better (Barin, 2006).

In dictation studies, since students always try to comprehend and write each word, the practice stays active until the end. In a sense, students fully remain in the position of being active during dictation and after dictation. Since all of the students experience to listen and write the same things at the same time, the presence of more or less of the class does not have a negative effect on the dictation (Bozkurt, Bulbul, \& Demir, 2014).

Another function of dictation emerges while teaching diction. Dictation is especially important for primary school students and individuals who start learning a foreign language. By the curtesy of dictation, the students get a chance to learn from their teachers how the words they are learning will be vocalized. Teachers are the guides for their students on how to spell words. Therefore, teachers need to be careful not to speak with the local mouth, to speak with the national mouth.

Even though the four basic language skills (reading, writing, listening, speaking) have the same importance in the literature, in society the person's knowledge of foreign language is measured by his/her success in listening and speaking. In other words, to see how much a Turkish learner got better, his/her speaking and listening skills get tested. Therefore, while teaching Turkish to foreigners, dictation studies should be utilized as much as possible in order to improve their listening and speaking skills.

Dictation has a very important place in written expression studies such as using words in the right place, writing letters and words correctly (Hamzadayi \& Cetinkaya, 2013). Brueckner \& Cutright (1927) has listed the benefits of written expression studies as follows:

Helps to use language knowledge rules effectively,

Extends the written vocabulary,

Develops good language standards,

Provides awareness in the use of words,

Improves the use of capital letters and punctuation,

Corrects specific grammatical forms and

Develops a sense of sentence.

When the qualities of dictation taken into consideration such as being an important skill; supporting the abilities of reading, writing, listening and speaking and other than these features, using it as a teaching technique when necessary and even as a measurement tool in order to determine the level of written expression it was determined that dictation studies were not used by teachers much. Because of both its geographical and political positions,

Turkish language teaching increasingly gained importance, studies on Turkish teaching have expanded and academic studies in this field have increased in terms of quantity and quality. However, as a result of the researches, the inadequacy of dictation studies required this study.

\section{Method}

\subsection{Research Objectives}

In the sequel of recent developments in Syria, the aim of the study is to practice dictation of writing success on the Syrian students who live in Turkey and learn Turkish.

\subsection{Research Method}

In the qualitative design study, the texts which were written by students were analyzed with content analysis method. Content analysis aims to figure out the concepts and relationships that can explain the collected data. In content analysis, concepts and themes that are similar to each other are organized under certain headings and organized in a way that the reader can understand (Yildirim \& Simsek, 2013, p. 227). Content analysis is the classification of written and oral data in terms of a problem or purpose, to summarize, and finding a meaning from certain variables and concepts (Fox, 1969: 646; as cited in Tavsancil \& Aslan, 2001, p. 20).

\subsection{Working Group}

The working group of this research consists of 19 Syrian students (7 males and 12 females) who are at level A2, 
studying at Mustafa Kemal University in 2017-2018 academic year in the age range of 20-24 and at level A2.

\subsection{Data Collection and Analysis}

In the qualitative research design, as a data collection tool dictation papers written by students were used. In this study, the work of Omer Seyfettin's Forsa was used. The texts dictated by the researcher were written by the students and the obtained data were evaluated from various perspectives. In the research carried out in a 4-week period, texts of different numbers of paragraphs and words were used.

Table 1. Text Parts Used in the Study

\begin{tabular}{lrr}
\hline Weeks & Paragraph (N) & Word (N) \\
\hline Week 1 & 3 & 117 \\
Week 2 & 4 & 121 \\
Week 3 & 2 & 92 \\
Week 4 & 3 & 152 \\
Total & $\mathbf{1 2}$ & $\mathbf{4 8 2}$ \\
\hline
\end{tabular}

The data collected through the texts are discussed in terms of the speed of completion of the dictation text, the writing speed and the status of writing words of Arabic origin. For this purpose, the stopwatch is used to calculate the start and end time of the applications and the amount of words written by the students in a minute. Following the applications, the correct and incorrect words of the students were determined and transferred to the Excel program and then the students were asked to write the Arabic words. Turkish Dictionary (2011) written by the Turkish Language Society and Info Dictionary of Turkish origin in Turkey Turkish Words by Gulensoy (2007) was used to determine the Arabic words in the research. During the determination of original Arabic words, suffixes taken by the words were ignored. In other words, a word which was passed from Arabic to Turkish at its root was accepted as the Arabic word. Also unified verbs and nouns from Arabic root were included in this group. Even one letter mistaken words were not accepted. On the other hand, all mistakes in capitalization were considered correct. The initials of the private names and the initial letters of the first words of sentences and the rules of separating the annexes from the special names were not taken into account. The data was reviewed twice to minimize the error.

\subsection{Materials}

In the study a text consists 12 paragraphs of 482 words were used. The completion times of the students are given in Table 2.

Table 2. The Completion Times of the Students

\begin{tabular}{lrrr}
\hline Weeks & $\begin{array}{r}\text { Number of } \\
\text { Words }\end{array}$ & Time (min.) & $\begin{array}{r}\text { Speed } \\
\text { (word/min.) }\end{array}$ \\
\hline Week 1 & 117 & 17,00 & 6,88 \\
Week 2 & 121 & 14,62 & 8,28 \\
Week 3 & 92 & 10,81 & 8,51 \\
Week 4 & 152 & 15,47 & 9,83 \\
Total & $\mathbf{4 8 2}$ & $\mathbf{5 7 , 9 0}$ & $\mathbf{8 , 3 2}$ \\
\hline
\end{tabular}

According to Table 2, it was understood that dictation studies increased the speed of students' writing works. In the first week, the students had a writing speed of 6,88 per minute, and they reached 9,83 words/minute in the $4^{\text {th }}$ week. It is also possible to determine writing speeds based on the words they wrote correctly by removing the words they wrote incorrectly or leaving it blank. The number of words students wrote and their speed are given in the Graph 1.

\section{Results}

Graph 1 shows that girls are above average and males have a percentage below average. Looking at the data obtained on the basis of weeks, high percentages were observed at the $1^{\text {st }}$ and $3^{\text {rd }}$ weeks, and the values decreased at the $2^{\text {nd }}$ and $4^{\text {th }}$ weeks. In terms of all weeks, it is seen that the average of girls is $71,7 \%$ and the average of males is $60,5 \%$ and the general average is $64,6 \%$. Furthermore, looking at the increasing success of writing a dictation text which is $63,6 \%$ at week 1 to $66,3 \%$ at week 4 suggests that dictation studies have an impact on students' writing success. 


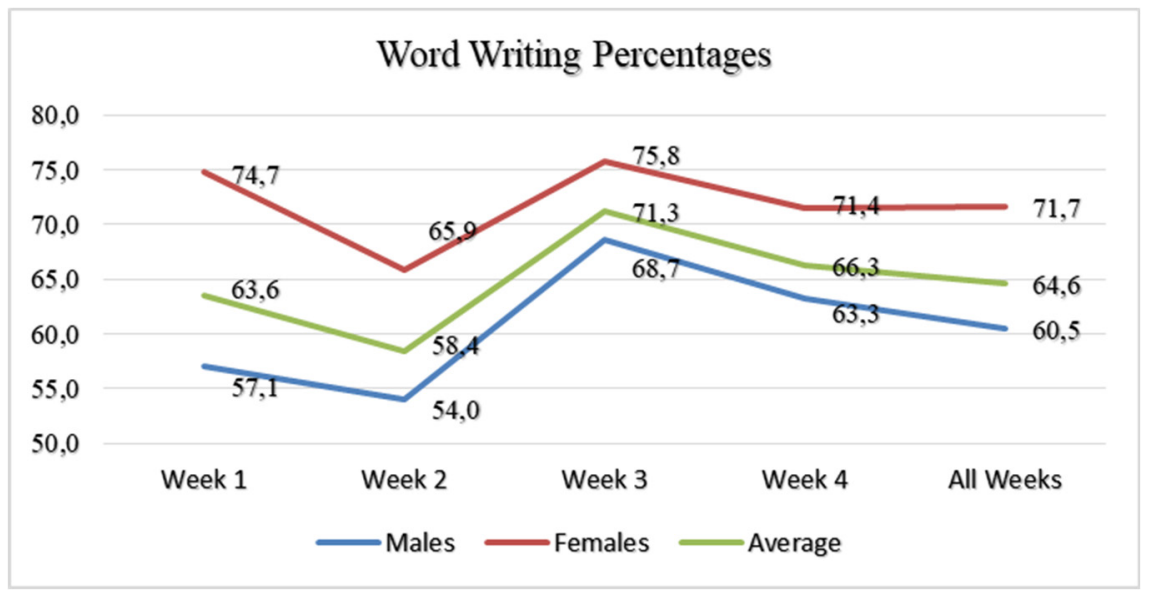

Graph 1. Word Writing Percentages

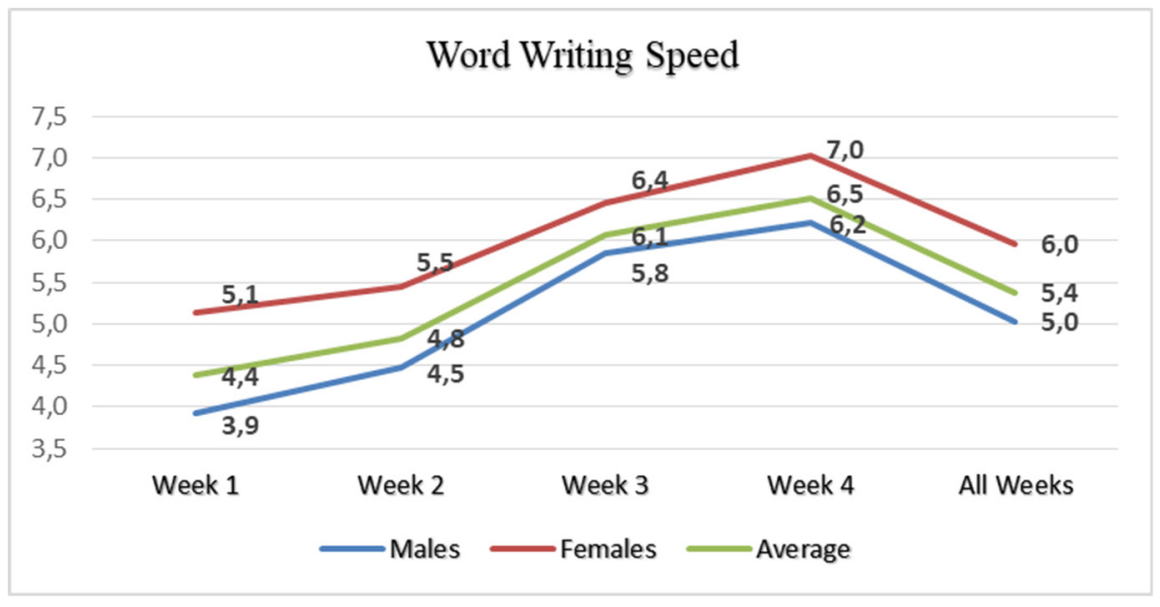

Graph 2. Word Writing Speeds

Graph 2 shows the number of words students wrote per minute. At the end of the $4^{\text {th }}$ week, the writing speed, which was 4,4 words/minute at the $1^{\text {st }}$ week, reached 6,5 words/minute. When the whole weeks were taken into consideration, the overall average was 5,4 words/minute. According to the graph, females wrote dictation texts at a higher average speed than males at all weeks of practice. Both females and males increased their writing speed a little more in each application. This situation shows that dictation studies have contributed to the writing speed of Syrian students positively.

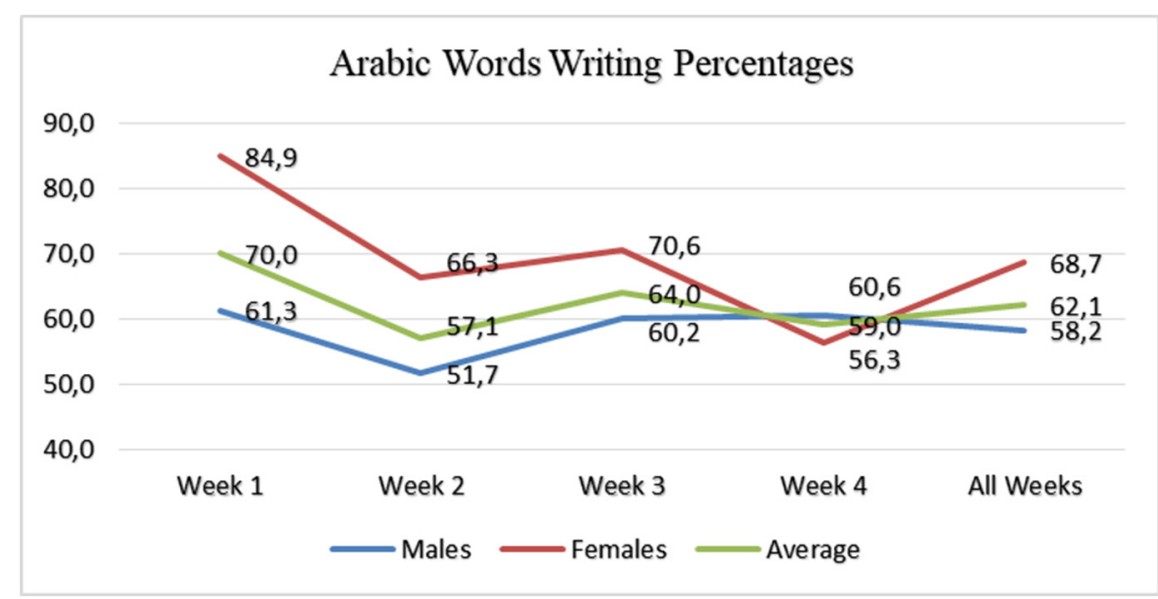

Graph 3. Arabic Word Writing Percentages 
In Graph 3, the percentages of Syrian students writing the words of Arabic origin from the dictation text are given. When the graph was reviewed, it was found that the percentage of students' writing was high in the $1^{\text {st }}$ and $3^{\text {rd }}$ weeks and lower in the $2^{\text {nd }}$ and $4^{\text {th }}$ weeks. Considering all weeks, it was determined that the level of achievement of females was $68,7 \%$, the level of achievement of males was $58,2 \%$ and the overall average achievement level was $62,1 \%$.

\section{Discussion}

In the current study, the text was dictated by the teacher. Some words were repeated a few times for the students' understanding the text better. According to Kazazoglu (2013), the rate of comprehending is more for a text dictated by a teacher than a text listened from a tape recorder. Additionally, diction of the reader of a text is crucial. Therefore, special attention was paid on the teacher to be sufficient in this regard.

The findings of the current study revealed that dictation practices increased the students' writing speed. Although there are no direct findings in the literature that dictation increases writing speed, there are some conclusions revealing that dictation is an effective tool in education. Likewise, Takeuchi (1997) found in his study that dictation is an efficient activity for foreign language teaching. It was suggested in the study carried out by Herusatoto (2017) that implementing dictation activities raised students' awareness about reproducing the texts they listened. Despite the fact that dictation seems very simple to be effective, it can be beneficial for improving students' skills of writing, listening and vocabulary (Gladwin-Chocolaad, 1986). It is also regarded as a useful activity for getting students adopt the habit of using sounds, letters and words accurately and of using a notebook (Gultekin \& Aktay, 2014). Contrarily, there are also some studies claiming that dictation is not effective enough because of some economical, technical or such reasons (Jafarpur \& Yamini, 1993; Lado, 1961; Bennett, 1968 \& Harris, 1969). However, most of the negative findings in these studies were related to use of dictation as an assessment tool, and there were few findings related to its use as an instructional tool.

Dictation practices help students see their own mistakes. For instance, in a study carried out by Gunday \& Kuscu (2012), French language prep students edited their own mistakes on the texts they had written, and their mistakes were lessened almost by half with the help of dictation practices. In our study, it was also observed that dictation activities contributed to the students for using punctuation marks accurately. Likewise, there are several studies in the literature suggesting that dictation activities help students lessen their mistakes about spelling and punctuation (Brueckner \& Cutright, 1927; Sutherkand, 1967; Hamzadayi \& Cetinkaya, 2013).

Dictation activities can easily be used in foreign language teaching. In our study, it was suggested that dictation practices affected Syrian students' writing skill in a positive way since success rate of their writing a dictated text which was $63,6 \%$ in the first week became $66,3 \%$ in the final week. The fact that Syrian students write in Arabic alphabet causes them to get confused with vowels of the Turkish language which is written in Latin alphabet. This fact affects number of words they write correctly. Conclusion of the study, "An evaluation of Arab students' Turkish writing skills", which was implemented by Bolukbas (2011) supports our study. In the current study, it was also found in the student interviews that the students had difficulty in writing vowels claiming that the vowels in their native language are illustrated with less signs. Similarly, it was concluded in a study carried out by Sengul (2014) that in most of the writings of the foreigners whose native language was Arabic and who used Arabic letters, vowels were not written. According to Tum (2016), the fact that Turkish is an agglutinative language causes students learning Turkish to have problems while writing words. Doing dictation activities in the class can be beneficial in eliminating these problems. By means of dictation practices, students can write letters and suffixes accurately. The study implemented by Cetinkaya \& Hamzadayi (2014) supports this idea. In that study which was carried out with 18 A2 students studying in Gaziantep University Turkish Language Teaching Center, dictation practices recovered their writing vowels $60 \%$, consonants $65 \%$ and suffixes $65 \%$.

In the current study, it was found that the girls wrote faster than the boys did. On the other hand, there are some studies that have different conclusions from our study. Gender did not create significant difference on dictation skill in the study implemented with EFL students by Poorsoti \& Aidinlou (2016), in the study carried out on American students by Demir \& Gulec (2015) and in the study held by Babayigit \& Erkus (2014).

Finally, the rate of Syrian students' spelling words of Arabic origin (62.1\%) was found to be lower than the rate of their spelling all words (64.6\%). This is far from the expectation of that "Syrian students write words of Arabic origin in Turkish better". That some words change in terms of pronunciation and some others get a different mode of articulation with suffixes can be the reason why they do not comprehend spelling of these words exactly. Some alterations occurred in the words of Arabic origin in terms of intonation and semantics since they have been used in Turkish contexts for centuries. In other words, the fact that Turkish language made the words of Arabic origin 
Turkish led similarities findings of dictation practices.

\section{Conclusions}

In the study, it was found that dictation studies increased the speed of completion of writing studies of students. In the first week, the students who completed 117 words in 17 minutes $(6,88$ word/minute) completed 152 words in 15,47 minutes $\left(9,83\right.$ word/minute) in $4^{\text {th }}$ week. Therefore, dictation studies can be used easily in foreign education.

The success of the writing was found by removing the wrongly written words and the words which were left blank. According to this, students wrote $64.6 \%$ ( $\mathrm{f}=311,3$ words) of 482 words correctly. Dictation texts were correctly written by $71,7 \%$ of females ( $f=345,4$ words) and $60,5 \%$ of males ( $f=291,4$ words). These values show that females are more successful in dictation than males.

Furthermore, the success of writing dictation text, which is $63.6 \%$ in the first week, goes up to $66.3 \%$ in the last week shows that dictation studies have a positive effect on the success of the Syrian students. The use of different alphabets affects the correct words that students write because they cause students to confuse the vowels in Turkish.

In the study, the writing speed of female students were 5,1 in the $1^{\text {st }}$ week and was found to be 7,0 words/minute in the $4^{\text {th }}$ week; and when looking at the male students in the $1^{\text {st }}$ week, it was found that the writing speed increased from 3,9 to 6,2 words/week in the $4^{\text {th }}$ week. This result shows that girls write a higher average speed than boys. Although the writing success of the students is not at the desired level, the amount of words written per minute has increased with every application week.

Lastly, when the Syrian students writing skills in Turkish evaluated it was stated that, females were at the level of $68.7 \%$, males were at the level of $58.2 \%$ and genereal average was at the level of $62.1 \%$. When compared with the above general result ( 482 words, $64.6 \%$ writing success), this result is far from meeting the expectation. In this case, it is not possible to say that Syrian students will write these words better because they are familiar with Arabic-origin words. The reason for this may be the Turkicization of Arabic words.

Because of the change in the some words' pronunciation (zaif => zayif) and some words with the appendix they get (nihayetsiz, ufuklarına, hayırdır, dikkatle etc.), students get confused with their spellings. The fact that the Arabic words in Turkish are being used in Turkish contexts for hundreds of years has caused changes in terms of both melody and meaning in these words. In other words, the fact that our language has been translated into Turkish by Arabic language may have made the results of dictation studies similar.

\section{Suggestions}

In dictation studies, students have improved their writing success and positively affected their foreign language learning. Therefore, dictation studies should be used when foreigners are taught the language. Dictation is not a skill that only concerns writing. It is also closely related to reading, speaking and listening skills. In addition, it is a great advantage for students to be able to collect their attention, even in crowded classes. The fact that it can be used in measurement and evaluation activities as a method also shows how useful dictation practices are. Therefore, it is necessary to ensure that the dictation is used effectively by teachers.

Teachers and instructors should be given the necessary theoretical and practical training for dictation studies. For this purpose, activities aimed at using different techniques developed in dictation in language teaching can be planned.

There are few academic studies investigating the impact of dictation studies on foreign language teaching. Researchers should conduct studies that deal with dictation and other skills comprehensively. Particular attention can be given to studies on dictation and pronunciation development.

\section{References}

Babayigit, O., \& Erkus, B. (2014). Evaluation of primary education 4 grade student's dictation skills. International Journal of Turkish Education Sciences, 2(2), 123-135.

Barin, E. (2006). Yurt disindaki Turk cocuklarina Turkce ogretiminde dikte ve yazili anlatimin onemi. TDAY Belleten, $1,21-32$.

Bennett, W. A. (1968). Aspects of language and language teaching. London, UK: Cambridge University Press.

Bolukbas, F. (2011). An evaluation of Arab students' Turkish writing skills. Electronic Turkish Studies, 6(3), 1357-1367. http://dx.doi.org/10.7827/TurkishStudies.2415 
Bozkurt, B., Bulbul, F., \& Demir, H. (2014). Dictation and teaching Turkish as a foreign language. Electronic Turkish Studies, 9(6), 59-173. http://dx.doi.org/10.7827/TurkishStudies.6662

Brueckner, L. J., \& Cutright, P. (1927). Dictation in teaching punctuation: A study to determine its effectiveness. The Elementary English Review, 4(9), 265-284.

Cetinkaya, G., \& Hamzadayi, E. (2014). The effect of phonemic text dictation practices on A2 level students' writing skills. Electronic Journal of Social Sciences, 13(49), 1-15. http://dx.doi.org/10.17755/esosder.84853

Coskun, İ., Taskaya, S. M., \& Bal, T. (2013). In the course Turkish the cases of making use of dictation exercises of elementary school teachers as a method of assessment and evaluation. Trakya University Journal of Social Science, 15(2), 1-16.

Demir, T., \& Gulec, İ. (2015). ABD uyruklu ogrencilerin A1 duzeyinde Turkce unlu sesletiminde karsilastiklari ortak sorunlar, Koc Universitesi ornegi. In I. Gulec, H. I. Saglam \& O. E. Akgun (Eds.), IV. Sakarya'da Egitim Arastırmaları Kongresi Bildiriler Kitabı (pp. 120-133). Sakarya: Sakarya Universtiy Publications.

Donger, A., Ozkartal, Z., \& Sarigoz, O. (2016). An investigation into variables that affect self efficacy beliefs of people working in educational institutions. International Refereed Academic Social Sciences Journal, 24, 1-17. http://dx.doi.org/10.17364/IIB.20162423324

Donger, A., Ozkartal, Z., \& Sarigoz, O. (2017). An Examination of anxiety levels of the students towards scientific research. International Refereed Journal of Humanities and Academic Science, 21, 22-36. http://dx.doi.org/10.17368/UHBAB.2017.3.1

Gladwin-Chocolaad, G. (1986). Dictation improves writing, listening, spelling and vocabulary. The Reading Teacher, 39(6), 609-610.

Gocer, A. (2010). Writing education in Turkish teaching. Journal of International Social Research, 3(12), 178-195.

Gogus, B. (1978). Orta dereceli okullarımizda Turkce ve yazin egitimi. Ankara: Gul Yayinevi.

Gulensoy, T. (2007). Turkiye Turkcesindeki Turkce sozcuklerin koken bilgisi. Ankara: Turk Dil Kurumu Yayinlari.

Gultekin, M., \& Aktay, E. G. (2014). Dictation activities in reading and writing instruction. Inonu University Journal of the Faculty of Education, 15(2), 19-44. http://dx.doi.org/10.17679/iuefd.43574

Gunday, R., \& Kuscu, E. (2012). Fautes/erreurs et leurs causes aux dictees des etudiants de la classe preparatoire de Francais. Ondokuz Mayis University Journal of Education Faculty, 31(2), 165-192.

Hamzadayi, E., \& Cetinkaya, G. (2013). The effect of dictation practices towards fifth grade students' skills to apply the rules of spelling and punctuation rules. Mersin University Journal of the Faculty of Education, 9(3), 133-143.

Harris, D. P. (1969). Testing English as a second language. New York: McGraw-Hill.

Hengirmen, M. (1990). Yabanci dil ogretim yontemleri ve Tomer yontemi. Ankara: Engin Yayincilik.

Herusatoto, H. (2017). Using dictation to promote the use of grammar knowledge in reconstructing listening Texts. Celt: A Journal of Culture, English Language Teaching \& Literature, 16(2), 217-241. https://doi.org/10.24167/celt.v16i2.763

Jafarpur, A., \& Yamini, M. (1993). Does practice with dictation improve language skills? System, 21, 359-369. https://doi.org/10.1016/0346-251X(93)90026-D

Kazazoglu, S. (2013). Dictation as a language learning tool. Procedia-Social and Behavioral Sciences, 70, 1338-1346. https://doi.org/10.1016/j.sbspro.2013.01.195

Lado, R. (1961). Language testing: The construction and use of foreign language tests. London: Longman.

MEB. (2015). Yabanci Diller Yabancilar icin Turkce Seviye A2 Moduler Programi. Ankara: Millî Egitim Bakanligi, Hayat Boyu Ogrenme Genel Mudurlugu.

Oz, F. (2011). Uygulamali Turkce ogretimi. Ankara: Ani Publication.

Ozcakmak, H. (2015). Pre-service Turkish language teachers' skills of using summarization strategies while taking notes by listening. Unpublished Doctorate Thesis, Gazi University Graduate School of Educational Sciences, Ankara, Turkey.

Poorsoti, S., \& Aidinlou, N. A. (2016). Effect of bilingualism on English dictation performance of male and female 
primary level students. Journal of Applied Linguistics and Language Research, 3(2), 39-50.

Rapp, B., \& Caramazza, A. (1997). From graphemes to abstract letter shapes: levels of representation in written spelling. Journal of Experimental Psychology-Human Perception and Performance, 23(4), 1130-1152. https://doi.org/10.1037/0096-1523.23.4.1130

Sengul, K. (2014). Alphabet issues in teaching Turkish as a foreign language. International Journal of Turkish Literature Culture Education, 3(1), 325-339. http://dx.doi.org/10.7884/teke.245

Sutherland, K. K. (1967). The place of dictation in the language classroom. TESOL Quarterly, 1(1), 24-29. https://doi.org/10.2307/3585909

Takeuchi, O. (1997). Dictation: Is it really effective for language teaching? Kansai University Audio Visual Education, 20, 155-161.

Tavsancil, E., \& Aslan, E. (2001). Icerik analizi ve uygulama ornekleri. İstanbul: Epsilon Yayincilik.

Tum, G. (2016). The place of dictation in teaching Turkish as a foreign language. Journal of Language Education and Research, 2(2), 29-40.

Turk Dil Kurumu. (2011). Turkce sozluk. Ankara: Turk Dil Kurumu Yayinlari.

Yalcin, A. (2002). Turkce ogretim yontemleri yeni yaklasimlar. Ankara: Akcag Yayinlari.

Yildirim, A., \& Simsek, H. (2013). Sosyal bilimlerde nitel arastırma yontemleri. Ankara: Seckin Yayinevi. 